\title{
Journal of Tropical Biodiversity and Biotechnology
}

journal homepage: http://jtbb.or.id

\section{Composition of Mitochondrial DNA 16S Nucleotide of Dwarf Snakehead (Channa gachua Hamilton, 1822) from Keji River, Magelang, Central Java}

\author{
Warisatul IImi, Tuty Arisuryanti*
}

Faculty of Biology, Universitas Gadjah Mada, Jl. Tehnika Selatan, Sekip Utara, Yogyakarta 55281.

*Corresponding author, email: tuty-arisuryanti@ugm.ac.id

\begin{tabular}{l} 
A R T I C L E I N F O \\
\hline Article history: \\
Received 18/05/2018 \\
Received in revised form 05/07/2018 \\
Accepted 07/07/2018
\end{tabular}

Keywords:

dwarf snakehead,

genetic characterization

mtDNA 16S

nucleotide composition

DOI: $10.22146 / j t b b .35613$

C 2018 JTBB
A B STR A C T

Indonesia has a high marine and freshwater biodiversity including freshwater fish biodiversity. One of freshwater fish which is commonly consumed by Indonesian people is dwarf snakehead (Channa gachua Hamilton, 1822). However, research on genetic characterization, especially the composition of mtDNA 165 nucleotide of dwarf snakehead has poorly understood. Therefore, the aim of this study was to determine the composition of mtDNA 16S nucleotide of dwarf snakehead as a part of genetic characterization of the fish species taken from Keji River, Magelang, Central Java which has not been previously examined. This study analyzed $16 \mathrm{~S} \mathrm{mt}$ DNA of two samples of dwarf snakehead from Keji River (KTS-01 and KTS-02). In addition, two sequences of Channa gachua with accession number KU986900, KU238074, and HM117234HM117238 taken from GenBank were used as a comparison. A method used in this research was a PCR method and primers used in this research were $16 \mathrm{Sar}$ and $16 \mathrm{Sbr}$. The results revealed that the average of nucleotide composition T, C, A and G of the fish species was $23.04 \%, 25.13 \%$, $29.06 \%$ and $22.77 \%$ respectively whereas the average rate of nucleotide composition $A+T$ and $\mathrm{G}+\mathrm{C}$ was $52.10 \%$ and $47.90 \%$ respectively. The two dwarf snakehead had similar $\mathrm{T}$ and $\mathrm{C}$ composition but different in A and G composition. In addition, the $\mathrm{G}+\mathrm{C}$ content in KTS-01 and KTS-02 had the highest frequency compared to other dwarf snakehead taken from GenBank. From this finding it could be assumed that there is genetic variation between the two dwarf snakehead from Keji River which is important genetic data for breeding program of the fish species in the future.

\section{Introduction}

Fish has important nutritional values especially protein, vitamin and minerals. Dwarf snakehead (Channa gachua) is one of freshwater fish which is commonly consumed by Indonesian people. The dwarf snakehead belonging to the family Channidae and considered as the important freshwater food fish in tropical Asia due to possess high economic value (Benziger et al., 2011; Kottelat, 2013). In addition, the fish are commonly used as ornamental fish in aquarium due to the beautiful colorization (Milton et al., 2011).

The fish is native to Asia and has widely distribution in Middle East and South Asia, including Indonesia (Berra, 2007; Kottelat, 2013). This species mainly inhabit most any type of wetland including streams, creeks and rivers with $\mathrm{pH}$ 6.0-7.0 and temperature $10-28^{\circ} \mathrm{C}$. The species can reach $28 \mathrm{~cm}$ in length and feeds on small fish, aquatic insects and crustaceans (Chaundhry, 2010).

In order to increase the production of the fish, research attention has to be focused on the fish genetic characterization using molecular approaches. Mitochondrial genes are widely used as efficient molecular tools not only for identification unambiguous species but also for examination genetic variation and biodiversity with high levels of accuracy (Pereira et al., 2008; Yang et al., 2014; Hammer et al., 2014; Satoh et al., 2016). One of the mitochondrial genes that can be used for molecular marker is $165 \mathrm{mtDNA}$. The $165 \mathrm{mt}-\mathrm{DNA}$ is often used for studies genetic characterization of the 
species and genetic variation at inter-specific levels, such as Coilia mystus (Cheng et al., 2008), Epinephelus lanceolatus (Cheng et al., 2015), Monopterus albus (Arisuryanti, 2016), and Labeo spp. (Jahan et al., 2017). For the analysis, the $16 \mathrm{~S}$ mtDNA marker is first amplified by PCR using primers (universal or specific primers) and the amplicons are sequenced. Sequencing data are then aligned and compared using appropriate bioinformatic tools (Arif and Khan, 2009; Arif et al., 2009).

Despite the importance of this species as a food consumption resource, little is known about genetic characterization and genetic diversity of dwarf snakehead in the Indonesian waters. The information of $165 \mathrm{mtDNA}$ varieties in C. gachua collected from Keji River (Magelang, Central Java) has never been reported. Failure to detect population units of the fish species coupled with local overfishing will ultimately lead to decrease in populations. In order to implement conservation and management strategies for a declining species, it is important to investigate composition of mitochondrial DNA 165 nucleotide of dwarf snakehead as a part of the fish genetic characterization throughout its natural habitat. Therefore, the objective of this research was to find the basic nucleotide data of the $16 \mathrm{~S}$ mtDNA of dwarf snakehead from Keji River (Magelang, Central Java) to complete the genetic information of Indonesian dwarf snakeheads. It is expected that this finding of this study is able to give genetic information which is beneficial for improving the genetic quality of dwarf snakeheads in Indonesia through breeding program.

\section{Materials and Methods}

\subsection{Materials}

The materials used were $100 \mathrm{mg}$ fillet of two samples of dwarf snakehead fish from Keji River, Magelang (Figure 2), 99\% ethanol, aquades, aquabides, Qiagen DNA isolation kits (Qiagen, USA), agarose ( $1^{\text {st }}$ Base, Singapore), double distilated water (ddH2O, $1^{\text {st }}$ Base, Singapore), DNA ladder (Bioline), TrisEDTA (TE, $1^{\text {st }}$ Base, Singapore), Tris-Borate-EDTA buffer (TBE, $1^{\text {st }}$ Base, Singapore), DNA ladder (Bioline), MyTaq HS Red mix PCR, $\mathrm{MgCl}_{2}$, FluoroSafe ( $1^{\text {st }}$ Base, Singapore), DNA template, 16Sar primer (5'-CGCCTGTTTATCAAAAACAT-3') and primer 16Sbr (5'- CCGGTCTGAACT CAGATCACGT-3') (Palumbi, 1996).

\subsection{Methods}

\subsubsection{Sample collection and storage}

The dwarf snakehead samples were collected from Keji River, Magelang, Central Java ( $\left.7^{\circ} 35^{\prime} 34.85^{\prime \prime} \mathrm{S} 110^{\circ} 16^{\prime} 19.48^{\prime \prime} \mathrm{E}\right)$ (Figure 1). The fish were caught by net and then documented
(Figure 2). Approximately $100 \mathrm{mg}$ of muscle tissue from two individuals (KTS-01 and KTS-02) was preserved in 99\% ethanol and each was placed into $1.5 \mathrm{ml}$ tube. Fish samples were then brought to Laboratory of Genetics and Breeding, Faculty of Biology, Universitas Gadjah Mada and stored at $4{ }^{\circ} \mathrm{C}$ until processed.

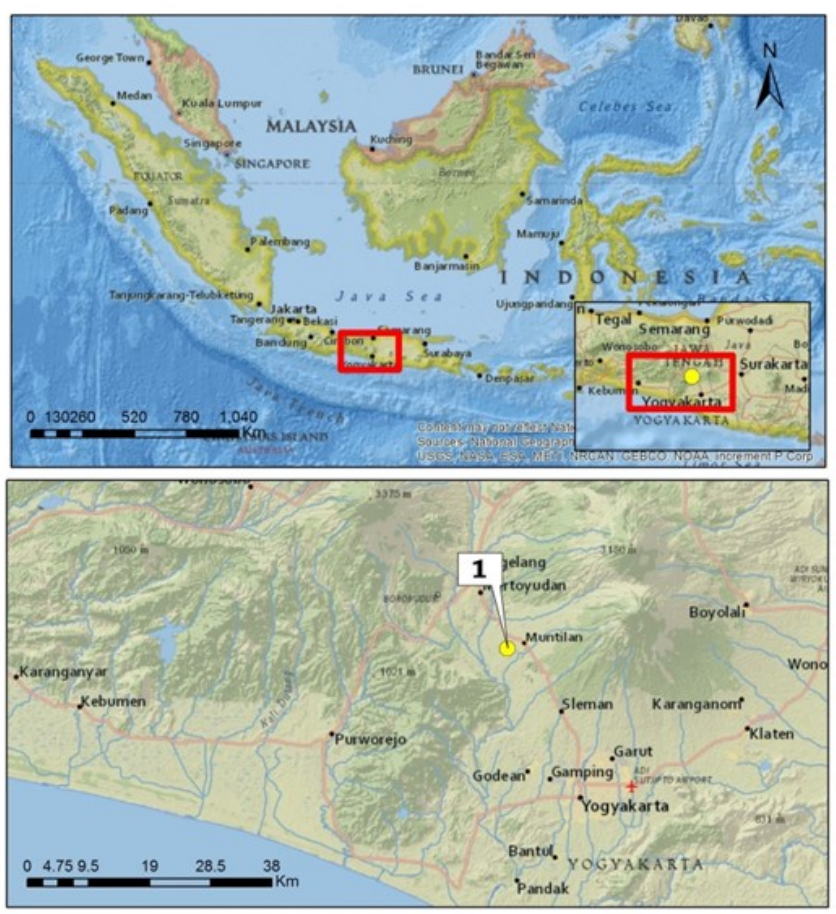

Figure 1. Map of sampling collection site for $C$. gachua samples in Keji River, Magelang, Central Java

\subsubsection{DNA isolation, $P C R$ amplification and electrophoresis}

Total genomic DNA was extracted from the ethanol preserved muscle tissue using the DNeasy blood and tissue kit (Qiagen, Valencia, CA, USA) following manufacture's protocols. The MyTaq HS Red Mix PCR kit (Bioline) was used for the polymerase chain reaction (PCR) and the primers used in this study were 16Sar (5'-CGCCT GTTTATCAAAAACAT-3') dan primer $16 \mathrm{Sbr}$ (5'- CCGGTCTGAACTCAGATCACGT-3') (Palumbi, 1996). The total volume of each PCR reaction was $50 \mu \mathrm{L}$. The reaction mixture consisted $10-100 \mathrm{ng}$ of genomic DNA, $25 \mu \mathrm{L}$ MyTaq HS Red Mix PCR, $2 \mathrm{mM} \mathrm{MgCl}, 0.6 \mu \mathrm{M}$ of each primer and $11 \mu \mathrm{L}$ double distilated water $\left(\mathrm{ddH}_{2} \mathrm{O}\right)$. A negative control was set up by omitting template DNA from the reaction mixture to evaluate the reliability of the DNA amplification. The reaction mixture was initially predenatured at $95^{\circ} \mathrm{C}$ for $5 \mathrm{~min}$ followed by 35 cycles of denaturation at $94^{\circ} \mathrm{C}$ for $35 \mathrm{~s}$, annealing at $50^{\circ} \mathrm{C}$ for $30 \mathrm{~s}$, and extension at $72^{\circ} \mathrm{C}$ for $30 \mathrm{~s}$. Reaction was then subjected to a final extension at $72{ }^{\circ} \mathrm{C}$ for 7 minutes. All of PCR products were visualized using $1 \%$ agarose gel electrophoresis buffered with Tris-Borate-EDTA (TBE), stained with FlouroSafe nucleic acid stain, and visualized under UV light. All samples were 
then sent to First Base Sdn Bhd (Malaysia) through P.T. Genetika Science (Jakarta) for purification and sequencing.

\subsubsection{Data analysis}

Chromatograms of the two dwarf snakeheads were checked and assembled using SeqMan, and edited using EditSeq Pro Program Lasergene DNASTAR software package (DNASTAR Inc., Madison, USA). Consensus sequences of the 165 mtDNA were checked from forward and reverse. The sequence of each sample was verified using BLAST. The composition of mtDNA $16 S$ nucleotide of each fish sequence obtained in this study were then calculated using DNA Statistics from EditSeq menu. The composition of $C+G$ was validated using DnaSP v.5.10.01 (Librado and Rozas, 2009). The comparison nucleotide composition of dwarf snakehead fish used was taken from GenBank (accession number KU986900, KU238074, and HM117234-HM117238).

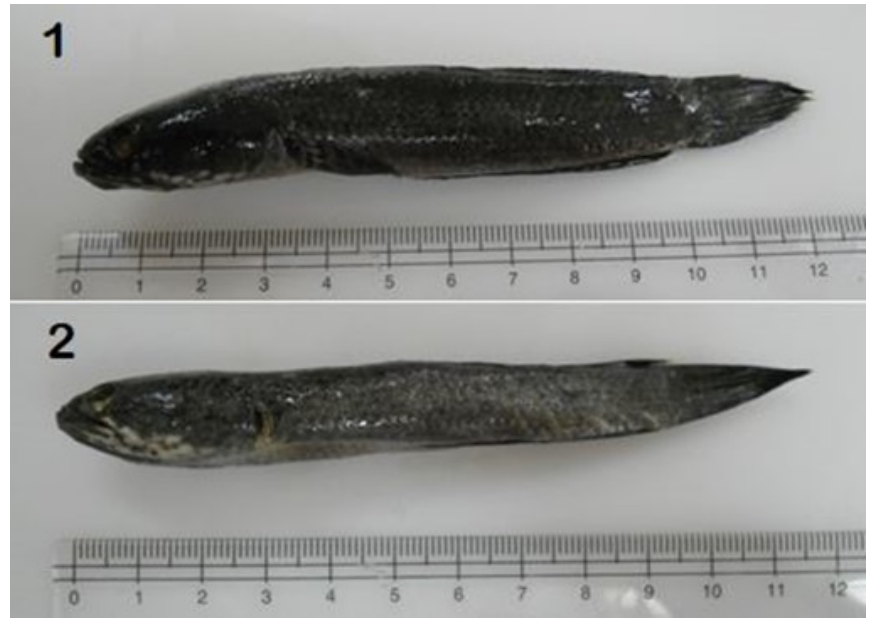

Figure 2. C. gachua collected from Keji River, Magelang, Central Java (1) KTS-01 and (2) KTS-02

\section{Results and Discussion}

The amplification product for the 165 mitochondrial gene of the two dwarf snakeheads investigated in this study (KTS-01 and KTS-02) generated 573 bp in fragment length (Figure 3). The analysis using BLAST showed that the two dwarf snakeheads investigated in this study have $98 \%$ similarity with C. gachua deposited at GenBank.

Tabel 1. Percentage composition of $16 \mathrm{~S}$ mtDNA nucleotide of $C$. gachua (KTS-01 and KTS-02) collected from Keji River, Magelang, Central Java

\begin{tabular}{lllllll}
\hline Sample & T(U) & C & A & G & A+T & C+G \\
\hline KTS-01 & 23.04 & 25.13 & 28.97 & 22.86 & 52.00 & 47.99 \\
KTS-02 & 23.04 & 25.13 & 29.14 & 22.69 & 52.18 & 47.82 \\
$\bar{x}$ & 23.04 & 25.13 & 29.06 & 22.77 & 52.10 & 47.90 \\
\hline
\end{tabular}

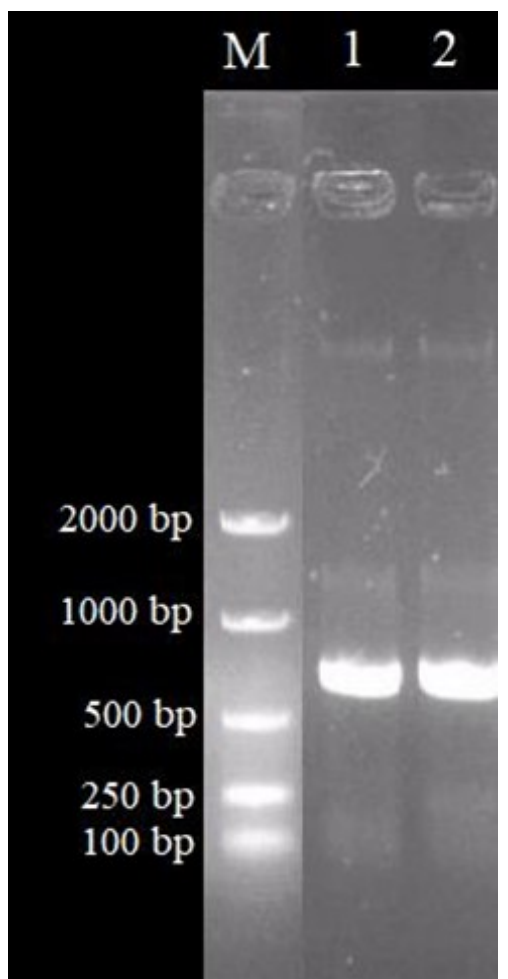

Figure 3. The DNA band profiles of 165 mitochondrial DNA of $C$. gachua (1) KTS-01 and (2) KTS-02. M = 1 kb DNA ladder (Bioline).

Based on the range of the analysis 573 bp nucleotide, the result of nucleotide parallelization of the two dwarf snakehead taken from Keji River (Magelang, Central Java) is shown on the Table 1. From the Table 1, it can be seen that the average of nucleotide T, C, A and G was $23.04 \%, 25.13 \%$, $29.06 \%$ and $22.77 \%$ respectively whereas the average rate of nucleotide composition $\mathrm{A}+\mathrm{T}$ and $\mathrm{G}+\mathrm{C}$ was $52.10 \%$ and $47.90 \%$ respectively. Both dwarf snakeheads had similar nucleotide $T$ and $C$ but different $A$ and $G$. The nucleotide divergence between the two $C$. gachua taken from Keji River indicated that there is intra-population genetic variation This is due to the $16 \mathrm{~S}$ mitochondrial gene is considered as a highly conserved and usually used for interspecies or intergeneric level of identification and diversity (Arif and Khan, 2009). Therefore, the finding of $16 \mathrm{~S}$ mtDNA nucleotide divergence between the two samples indicate that there is intrapopulation genetic variation which is important genetic data for breeding program of the fish species in the future.

Next, the $16 S$ mtDNA sequence data of C. gachua collected from Keji River (Magelang, Central Java) were compared to C. gachua taken from GenBank (KU986900 from Malaysia, KU238074 from China and HM117234-HM117238 from India) and it can be shown in Table 2. From the Table 2, it can be seen that the composition of nucleotide $C$ from $C$. gachua examined in this study has the highest frequency compared to the two other $C$. gachua from Malaysia and China. Similarly, the composition of $C+G$ of $C$. gachua from Keji River is also higher than that of $C+G$ from Malaysia and 
Tabel 2. Percentage composition of mtDNA 165 nucleotide of $C$. gachua (KTS-01 and KTS-02) collected from Keji River, Magelang, Central Java compared to other $C$. gachua samples taken from GenBank.

\begin{tabular}{llllllll}
\hline Sample & T(U) & C & A & G & A+T & C+G \\
\hline KTS-01 & 22.76 & 25.10 & 29.57 & 22.57 & 52.33 & 47.66 \\
KTS-02 & 22.76 & 25.10 & 29.77 & 22.37 & 52.53 & 47.47 \\
KU986900* & 23.54 & 24.31 & 30.35 & 21.79 & 53.89 & 46.11 \\
KU238074* & 23.15 & 24.51 & 29.96 & 22.37 & 53.11 & 46.89 \\
HM117234* & 22.42 & 25.40 & 30.55 & 21.63 & 52.98 & 47.02 \\
HM117235* & 22.42 & 25.20 & 30.55 & 21.83 & 52.98 & 47.02 \\
HM117236* & 22.42 & 25.20 & 30.55 & 21.83 & 52.98 & 47.02 \\
HM117237* & 22.42 & 25.20 & 30.55 & 21.83 & 52.98 & 47.02 \\
HM117238* & 22.42 & 25.20 & 30.55 & 21.83 & 52.98 & 47.02 \\
\hline
\end{tabular}

*Sample taken from GenBank

China which was previously examined and deposited to GenBank but unfortunately it has not been published. In addition, the composition of nucleotide $\mathrm{T}$ and $\mathrm{G}$ from $C$. gachua examined in this study has the highest frequency compared to the other five C. gachua from India. Similarly, the composition of $\mathrm{C}+\mathrm{G}$ of $C$. gachua from Keji River is also higher than that of $\mathrm{C}+\mathrm{G}$ from India which was previously examined by Lakra et al. (2010).

Based on the 165 mtDNA sequence data, the dwarf snakeheads (C. gachua) from Keji River (Magelang, Central Java, Indonesia) have had a specific nucleotide bases that distinguish them from $C$. gachua outside Indonesia, so it can be location-specific genetic markers from Keji River. This finding is important for developing policies regarding the conservation of the fish species and their habitat. Further research has to be examined on this fish species especially investigating the fish genetic variation through hyper variable mitochondrial gene (D-loop) and also microsatellite.

\section{Conclusions}

The average of nucleotide composition T, C, A and G of the $C$. gachua from Keji River (Magelang, Central Java) was $23.04 \%, 25.13 \%, 29.06 \%$ and $22.77 \%$ respectively whereas the average rate of nucleotide composition $\mathrm{A}+\mathrm{T}$ and $\mathrm{G}+\mathrm{C}$ was $52.10 \%$ and $47.90 \%$ respectively. The two $C$. gachua had similar $\mathrm{T}$ and $\mathrm{C}$ composition but different in $\mathrm{A}$ and $\mathrm{G}$ composition. In addition the $C$. gachua have had specific nucleotide composition compared to other $C$. gachua from outside Indonesia which can be used as a molecular marker for the fish species.

\section{Acknowledgement}

We thank Lukman Hakim, S.Si. for his kind help in drawing the map and providing valuable technical assistance in the laboratory and valuable technical advice concerning the computational analysis. In addition, we would like to express our sincere thanks to Head of Laboratory of Genetics and Breeding for providing facilities for this research.

\section{References}

Arif, I.A., Khan, H.A., Bahkali, A.H., Al Homaidan, A.A., Al Farhan, A.H., Shobrak, M. \& Al Sadoon, M., 2009, Comparison of neighbor-joining and maximum parsimony methods for molecular phylogeny of Oryx species using 12S rRNA and 16S rRNA gene sequences, Animal Biology Journal, 1(2), 117-125.

Arif, I.A. \& Khan, H.A., 2009, Molecular markers for biodiversity analysis of wildlife animals: a brief review, Animal Biodiversity and Conservation, 32(1), 9-17.

Arisuryanti, T., 2016, Molecular Genetic and Taxonomic Studies of the Swamp Eel (Monopterus albus Zuiew 1793). Ph.D. Thesis, Charles Darwin University, Australia.

Benziger A., Philip, S., Raghavan, R., Ali, P.H.A., Sukumaran8, M., Tharian, J.S., Dahanukar, N., Baby, F., Peter, R., Devi, K.R., Radhakrishnan, K.V., Haniffa, M.A., Britz, R. \& Antunes, A., 2011, Unraveling a 146 years old taxonomic puzzle: Validation of Malabar snakehead, species-status and its relevance for Channid systematics and evolution, Validation of Malabar Snakehead Species-Status, 6(6), 1-12.

Berra, T.M., 2007, Freshwater Fish Distribution, The University of Chicago Press, Chicago.

Chaundhry, S., 2010, 'Channa gachua', in The IUCN Red List of Threatened Species 2010, viewed 05 January 2018, from http://www.iucnredlist.org/details/166123/0. 
Cheng, Q., Ma, C., Cheng, H. \& Zhang, Q., 2008, Mitochondrial DNA diversity of Coilia mystus (Clupeiformes: Engraulidae) in three Chinese estuaries, Environmental Biology of Fishes, 83(3), 277-282.

Cheng, S.S., Senoo, S., Siddiquee, S. \& Rodrigues, K.F. 2015. Genetic variation in the mitochondrial genome of the giant grouper Epinephelus lanceolatus (Bloch, 1790) and its application for the identification of brood stock, Aquaculture Reports, 2, 139-143.

Hammer, M.P., Unmack, P.J. \& Adams, M., 2014, A multigene molecular assessment of cryptic biodiversity in the iconic freshwater blackfishes (Teleostei: Percichthyidae: Gadopsis) of south-eastern Australia, Biological Journal of the Linnean Society, 111, 521-540.

Jahan, H., Akter, M., Begum, R.A. \& Shahjahan, R.M., 2017, Identification and comparison of three carp fishes based on mitochondrial 16S rRNA gene. Journal Biological Science, 26(2), 167-174.

Kottelat, M., 2013, The fishes of the inland waters of Southeast Asia: A Catalogue and core bibliography of the fishes known to occur in freshwaters, mangroves and estuaries, The Raffles Bulletin of Zoology, 27, 1663.

Lakra, W.S., Goswami, M., Gopalakrishnan, A., Singh, D.P., Singh, A., Nagpure, N.S., 2010, Genetic relatedness among fish species of Genus Channa using mitochondrial DNA genes. Biochemical Systematics and Ecology, 38(6), 1212-1219.
Librado, P. \& Rozas, J., 2009, DnaSP v5: A Software for Comprehensive Analysis of DNA Polymorphism Data, Bioinformatics, 25, 1451-1452.

Milton, J., Bhat, A.A., Haniffa, M.A., Hussain, S.A., Rather, I.A., Al-Anazi, K.M., Hailan, W.A.Q. \& Farah, M.A., 2017, Ovarian development and histological observations of threatened dwarf snakehead fish, Channa gachua (Hamilton, 1822), Saudi Journal of Biological Sciences, 1(25), 149-153.

Palumbi, S.R., 1996, 'Nucleid acids II : The Polymerase Chain Reaction', in D.M. Hillis, C. Moritz, B.K. Mable (eds.), Molecular Systematic, pp. 205-247, Sinauer Associates, Massachusetts.

Pereira, F., Carneiro, J. \& Amorim, A., 2008, Identification of species with DNA-Based Technology: Current progress and challenges. Recent Patents on DNA and Gene Sequences, 2, 187-200.

Satoh, T.P., Miya, M., Mabuchi, K. \& Nishida, M., 2016, Structure and variation of the mitochondrial genome of fishes. Biomed Central Genomics, 17(719), 1-20.

Yang, L., Tan, Z., Wang, D., Xue, L., Guan, M., Huang, T. \& Li, R., 2014, Species identification through mitochondrial rRNA genetic analysis. Scientific Reports, 4, 4089. 